УДК 691

DOI: $10.22363 / 1815-5235-2018-14-3-216-225$

\title{
CREEP OF POLYTETRAFLUOROETHYLENE UNDER VARIOUS LOADING CONDITIONS
}

\author{
L.I. OGORODOV, I.P. NICKOLAEVA, E.L. YAKOVLEVA, O.V. FOMINYKH \\ Peter the Great Saint-Petersburg Polytechnic University \\ 29 Polytechnicheskaya St., St. Petersburg, 195251, Russia \\ (received: March 14, 2018; accepted: April 27, 2018)
}

\begin{abstract}
This article contains results of experimental research of polytetrafluoroethylene (PTFE) deformation and creep under linear and plane stresses. During the tests predetermined values of real stresses considering current deformation were constant. The equation of mechanical states considering instant elastic, viscoelastic, instant plastic and viscoplastic components of total deformation was obtained. The equation is used for the description of PTFE deformations (F-4, F-4D, F-4D0) under stationary and non-stationary cyclic loads in flat stress condition with an application of material constant volume condition, condition of similarity of deviators of stresses and deformations and with the input of parameters which are functions of the form of stress deviators. The results of PTFE creep investigation under real stresses reaching ultimate values are relevant and unique.
\end{abstract}

Keywords: creep, polytetraftorethylene, mechanical equation of states, static loadings, cyclic loadings, flat stress state, ultimate deformations

\section{ПОЛЗУЧЕСТЬ ПОЛИТЕТРАФТОРЭТИЛЕНА ПРИ РАЗЛИЧНЫХ УСЛОВИЯХ НАГРУЖЕНИЯ}

\author{
Л.И. ОГОРОДОВ, И.П. НИКОЛАЕВА, Е.Л. ЯКОВЛЕВА, О.В. ФОМИНЫХ \\ Санкт-Петербургский политехнический университет Петра Великого \\ ул. Политехническая, д. 29, Санкт-Петербург, Российская Федераиия, 195251 \\ (поступила в редакизию: 14 марта 2018 г.; принята к публикаичии: 27 апреля 2018 г.)
}

\begin{abstract}
В статье представлены результаты экспериментальных исследований деформации и ползучести политетрафторэтилена (ПТФЭ) при линейных и плоских напряженных состояниях. Во время испытаний заданные значения истинных напряжений с учетом текущей деформации были постоянными. Получено уравнение механических состояний, учитывающее мгновенноупругие, вязкоупругие, мгновеннопластические и вязкопластические компоненты полной деформации. Уравнение используется для описания деформаций ПТФЭ (F-4, F-4D, F-4D0) при стационарных и нестационарных циклических нагрузках в условиях плоского напряженного состояния с применением условия постоянства объема материала, условия подобия девиаторов напряжений и деформаций и ввода параметров, которые являются функциями вида девиаторов напряжений. Результаты исследования ползучести ПТФЭ при реальных напряжениях, достигающих предельных значений, являются актуальными и уникальными.
\end{abstract}

Ключевые слова: ползучесть, политетрафторэтилен, механическое уравнение состояний, статические нагрузки, циклические нагрузки, плоское напряженное состояние, конечные деформации

Introduction. One of the directions of the development of engineer durability calculations of structural elements theory is consideration of their rheonomous properties in order to describe the processes of long-term deforming and destruction. From the one hand, for calculating creep and long-term durability of structural elements it is necessary to use the equation of mechanical states which describes complicated deformation processes. From the other hand, kinematic equation of damages should be used in deformation type. The materials show rheonomous and hereditary features in deformation processes as well as in long-term destruction. Despite of the fact that there are a lot of theoretical and experimental researches, the question of choosing adequate description method of deformational processes for different classes of polymer materials under non-stationary loading and complex stress cannot be finally solved, 
especially in the most complex thermomechanical loadings [1-7]. The requirements of practical applicability for the resulting mechanical state equation in some cases of cyclic loading makes us to make a compromise in accuracy while describing complex deformation processes. The task is to reduce this compromise to the logical minimum.

The development of cyclic creep model provides new opportunities for experimental research task formulation, makes experiment purposeful and allows to choose test program for checking the theory.

Research targets. Studies of creep of partially crystal polymer and composite materials on polymer base remain topical. The influence of complex static and cyclic stress state and non-stationary loading conditions on deformation process mostly remains unclear.

Research targets are:

1. According to the short-term monotonic loading tests data, to make up an equation of mechanical states in terms of real stresses and deformations under complex stress state for direct and reverse creep for three modifications of tetrafluoroethylene.

2. To research and to describe creep of the same materials under non-stationary static and cyclic stationary and non-stationary loading

3 . To make a conclusion about the possibility of formularization of destruction deformation criteria for studied materials.

Materials and testing method with predetermined intensity of real stresses. The samples were made of pipe blanks of polytetrafluoroethylene F-4, F-4D by turning on the lathe tool and part of F-4D blanks were annealed; $\mathrm{F}-4 \mathrm{D}_{0}$ blanks were heated until $80{ }^{\circ} \mathrm{C}$ with the following cooling in the heating stove. The degree of materials' crystallinity was detected by German - Weidinger's method and it is: $30 \%$ for F-4, $45 \%$ for $\mathrm{F}-4 \mathrm{D}, 38 \%$ for inner surface of $\mathrm{F}-4 \mathrm{D}_{0}, 25 \%$ for outer surface of $\mathrm{F}-4 \mathrm{D}_{0}$. The densities of these materials are: for F- $4-2.25 \mathrm{~g} / \mathrm{sm}^{2}$, for F-4D and for $\mathrm{F}-4 \mathrm{D}_{0}-2.23 \mathrm{~g} / \mathrm{sm}^{2}$.

The samples were thin-walled tubes with the wall thickness $t_{0}=1.0 \mathrm{~mm}$ in working part and the length of working part $l_{p}=120 \mathrm{~mm}$. The outer diameter $\left(\mathrm{D}_{0}\right)$ of F-4 and F-4D working parts is $23.5 \mathrm{~mm}$, for F-4D $26 \mathrm{~mm}$. The wall thickness fluctuations along the working part did not exceed $0.05 \mathrm{~mm}$. The fluctuations of working parts lengths were within $\pm 1 \mathrm{~mm}$ and the fluctuations of outer diameter - within $\pm 0.1 \mathrm{~mm}$. The samples were fixed in special sealing caps.

Sample tests were held on equipment $[25 ; 26]$, which allow to study mechanical properties of materials under biaxial stress state with static and cyclic loading.

Lateral sample deformation was measured on the base $l_{0}=50 \mathrm{~mm}$ by optical system with the value of division $0.01 \mathrm{~mm}$. Transverse deformation was measured by arrow indicator. Temperature was $22 \pm 1^{\circ} \mathrm{C}$.

The intensity of real stress values for tubular sample under flat stress state with static loading was obtained by formula:

$$
\sigma_{i}=\frac{1}{\sqrt{2}} \sqrt{\left(\overline{\sigma_{x}}-\overline{\sigma_{\theta}}\right)^{2}+{\overline{\sigma_{x}}}^{2}+{\overline{\sigma_{\theta}}}^{2}} .
$$

Under cyclic loading the intensity of maximum stress value per cycle was obtained by formula:

$$
=\frac{1}{\sqrt{2}} \sqrt{\left({\overline{\sigma_{x}}}^{\max }-{\overline{\sigma_{\theta}}}^{\max }\right)^{2}+\left({\overline{\sigma_{x}}}^{\max }\right)^{2}+\left({\overline{\sigma_{\theta}}}^{\max }\right)^{2}} .
$$

Real stress components (axial $\overline{\sigma_{x}}$ and tangential $\left.\overline{\sigma_{\theta}}\right)$ were measured with considering current values of outer diameter $(D)$ and thickness of the wall $(t)$. The thickness of the wall was measured from the condition of constant value. The ratio between main stress components $n=\sigma_{x} / \sigma_{\theta}$ was established by choice of equipment plunger pair [25]. The delay time of equipment adjustment was not exceed 2 minutes, besides the fluctuations of stress intensity were not exceed $5 \%$ from set value of stress intensity $\sigma_{i}$ or $\sigma_{i}{ }^{\max }$ and fluctuations $n$ were not exceed $6 \%$.

Obtained experimental data under short time loading and creep with static loading are presented in the form of deformation curves in coordinates $\sigma_{i}-\varepsilon_{i}$ and creep curves in coordinates $\varepsilon_{i}{ }^{\max }-\tau$. The intensity of real (logarithmic) stresses were obtained by formula:

$$
\varepsilon_{i}=\frac{\sqrt{2}}{2} \sqrt{\left(\varepsilon_{x}-\varepsilon_{\theta}\right)^{2}+\left(\varepsilon_{\theta}-\varepsilon_{\tau}\right)^{2}+\left(\varepsilon_{\tau}-\varepsilon_{x}\right)^{2}} .
$$

Real deformation components $\varepsilon_{x}, \varepsilon_{\theta}, \varepsilon_{\tau}$ were obtained by following dependences, considering current sample dimensions $D, t$ and current base $l$ (the sample length):

$$
\varepsilon_{x}=\ln \frac{l}{l_{0}} ; \quad \varepsilon_{\theta}=\ln \frac{D-t}{D_{0}-t_{0}} ; \quad \varepsilon_{\tau}=\ln \frac{t}{t_{0}} .
$$

Lode's parameter for stresses is calculating:

$$
\mu_{S}=2 \frac{\sigma_{2}}{\sigma_{1}}-1 \mu_{S}=2 \frac{\sigma_{2}}{\sigma_{1}}-1,
$$

where $\sigma_{1}$ and $\sigma_{2}$ - the main stresses.

Tests results. Polytetrafluoroethylene deformation under short time loading. Short time loading PTFE deformation tests were held under linear and flat stress states with various ratios of axial and tangential stresses $\left(n=\sigma_{x} / \sigma_{\theta}\right)$ in conditions of proportional loading. For PTFE there is an influence of stress state type on deformation curve, besides the material shows the highest rigidity when the ratio $\sigma_{x} / \sigma_{\theta}$ is close to equiaxial tension and the lowest when it is under linear stress state. The variation of 
the loading speed from $0.03 \mathrm{MPa} / \mathrm{sec}$. to $0.3 \mathrm{MPa} / \mathrm{sec}$. influences on the deformation curves insignificantly.

The law of immediate deformation was studied by tests on the fast sample unloading from the fixed level of stress intensity under various types of stress state. Nonlinear dependences of instantly elastic deformation from stress intensities for studied fluoroplastics are presented in an article [26]. According to the results of the measurements, the transverse deformation coefficient values under axial tension are vary from 0.3 to 0.48 .

For the selection of the law of instant plastic deformation (the term is conditional) the data of the tests on the multiple loading with the speed $d \sigma_{i} / d t=0.1-0.3 \mathrm{MPa} / \mathrm{sec}$., with the registration of the $\sigma_{\mathrm{i}}$ and $\varepsilon_{\mathrm{i}}$ levels and further instant sample unloading was used. After exposure of at least one hour, permanent (instant elastic) deformations were measured. The dependence of instant plastic fluoroplastics deformations from the stress intensity is presented in the article [27]. Instant plastic deformations of fluoroplastics depend on the type of the stress state.

Direct and reverse creep under static loading. Direct creep is the increase of deformations in time under permanent real stresses (i.e. under constantly decreasing loads) (fig. 1-3). Complete deformation is the sum of four components: instant elastic, instant plastic, viscoplastic, viscoelastic [7-13]. To study viscoelastic creep deformation the tests on reverse creep (fig. 4-6) were held (returning after loading).

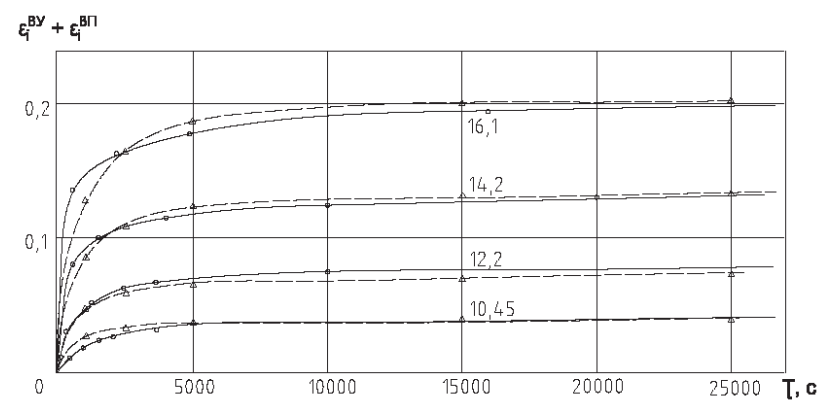

Fig. 1. Rheonomic $F-4 D_{0}$ creep dependence $(n=0.5)$ under various intensities of real stresses $\sigma_{i}$ : $o$ - experimental curves; $\Delta$ - calculated curves

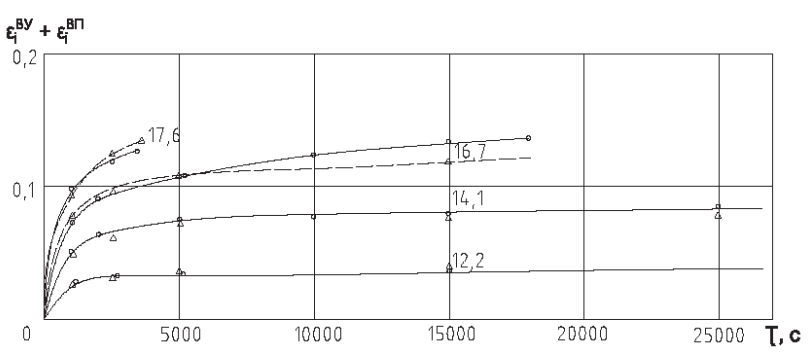

Fig. 2. Rheonomic $F-4 D_{0}$ creep dependence $(n=1.15)$ under various intensities of real stresses $\sigma_{i}$ : $\mathrm{o}$ - experimental curves; $\Delta$ - calculated curves

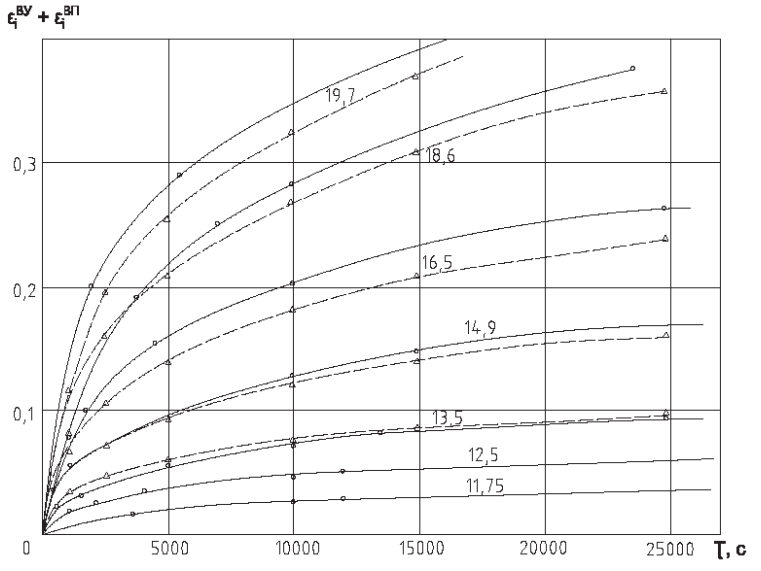

Fig. 3. Rheonomic F-4D creep dependence $(n=0.5)$ under various intensities of real stresses $\sigma_{i}$ : $o$ - experimental curves; $\Delta$ - calculated curves

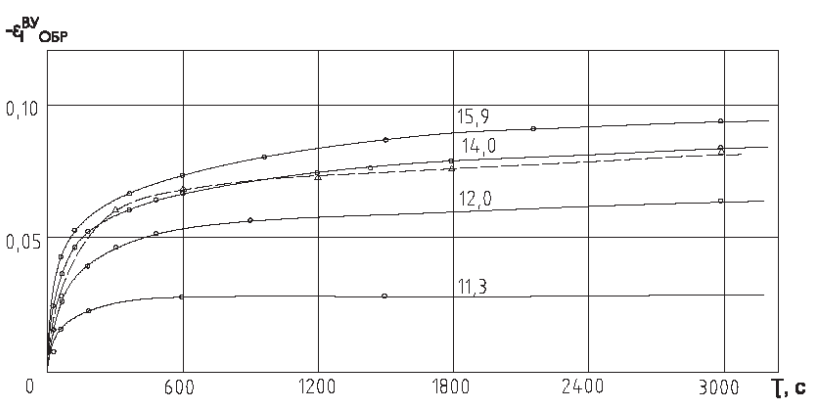

Fig. 4. Reverse F-4 creep curves $(n=0.5)$ under various intensities of real stresses $\sigma_{i}$ : o- experimental curves; $\Delta$ - calculated curves

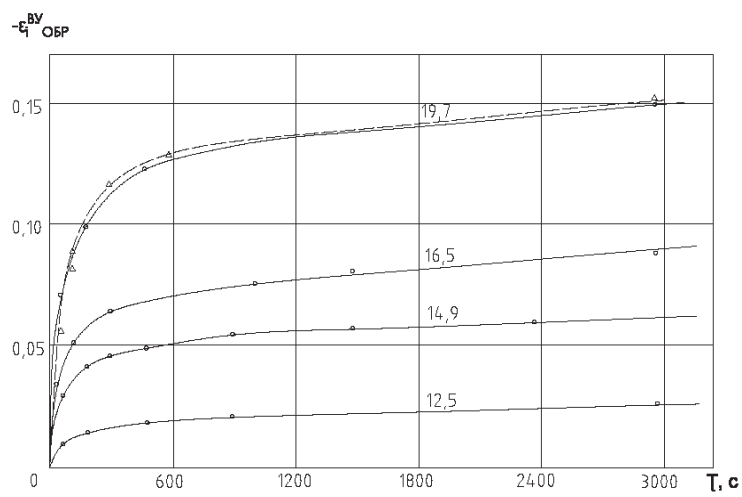

Fig. 5. Reverse F-4D creep curves $(n=0.5)$ under various intensities of real stresses $\sigma_{i}$ : o - experimental curves; $\Delta$ - calculated curves

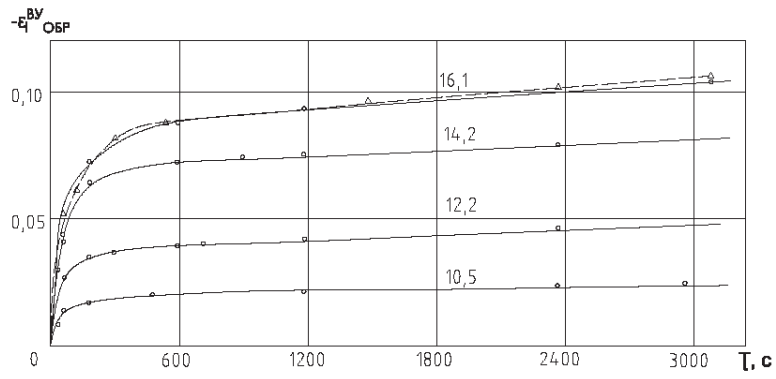

Fig. 6. Reverse $F-4 D_{0}$ creep curves $(n=0.5)$ under various intensities of real stresses $\sigma_{i}$ : o- experimental curves; $\Delta$ - calculated curves 
As a result, the complete equation of mechanical states in stress and deformation intensities $\left(\sigma_{i}, \varepsilon_{i}\right)$ under stationary loading was obtained, besides the condition of deformation speeds and stress deviators similarity is observed [27]:

$$
\begin{aligned}
& \varepsilon_{i}=\frac{2(1+v) \sigma_{i}}{3 E_{0}\left(1-\frac{\sigma_{i}}{\sigma_{* *}}\right)}+\gamma\left[\left(\alpha-\beta \mu_{S}\right) e^{m\left(\frac{\sigma_{i}}{\sigma_{x}}\right)}-1\right]+ \\
& +\int_{0}^{\tau}\left(a-b \mu_{S}\right) c \frac{\sigma_{i}}{\sigma_{*}}\left[A_{1} e^{-\frac{\tau}{\mu_{1}}}+A_{2} e^{-\frac{\tau}{\mu_{2}}}\right] d \theta+ \\
& +\int_{0}^{\tau}\left(d-l \mu_{S}\right) k\left(\frac{\sigma_{i}}{\sigma_{*}}-\delta\right)\left[A_{3} e^{-\frac{\tau}{x}}\right] d \tau .
\end{aligned}
$$

\begin{tabular}{|c|c|c|c|}
\hline \multirow{2}{*}{ Parameters } & \multicolumn{3}{|c|}{ Studied materials } \\
\hline & F-4 & F-4D & $F-4 D_{0}$ \\
\hline $\mathrm{E}_{0}, \mathrm{MPa}$ & 800 & 900 & 615 \\
\hline$\sigma_{* *}, \mathrm{MPa}$ & 27.5 & 28.5 & 22.5 \\
\hline $\mathrm{v}$ & $0.48 / 0.50$ & $0.48 / 0.50$ & $0.48 / 0.50$ \\
\hline$r$ & $1 \cdot 10^{-2}$ & $1 \cdot 10^{-2}$ & $1 \cdot 10^{-2}$ \\
\hline$\alpha$ & 0.05 & 0.20 & 0.25 \\
\hline$\beta$ & 0.03 & 0.06 & 0.08 \\
\hline $\mathrm{m}$ & 2.80 & 1.65 & 2.20 \\
\hline$\sigma_{*}, \mathrm{MPa}$ & 10 & 10 & 10 \\
\hline $\mathrm{a}$ & 1 & 1 & 1 \\
\hline $\mathrm{b}$ & 0.1 & 0.1 & 0.6 \\
\hline $\mathrm{c}$ & 0.30 & 0.08 & 0.26 \\
\hline $\mathrm{n}$ & 3.2 & 3.7 & 2.8 \\
\hline $\mathrm{A}_{1}$ & $5.5 \cdot 10^{-2}$ & $11 \cdot 10^{-4}$ & $9.5 \cdot 10^{-4}$ \\
\hline $\mathrm{A}_{2}$ & $1.7 \cdot 10^{-2}$ & $1.8 \cdot 10^{-4}$ & $1.8 \cdot 10^{-4}$ \\
\hline$\mu_{1}$, sec. & 110 & 110 & 85 \\
\hline$\mu_{2}$, sec. & 2475 & 3200 & 3000 \\
\hline d & 1 & 1 & 1 \\
\hline 1 & 0.3 & 0.3 & 0.5 \\
\hline$\delta$ & 1.05 & 1.18 & 1.17 \\
\hline $\mathrm{k}$ & 3.95 & 1.89 & 4.00 \\
\hline $\mathrm{A}_{3}$ & $7 \cdot 10^{-6}$ & $14 \cdot 10^{-6}$ & $26 \cdot 10^{-6}$ \\
\hline æ, sec. & $14.0 \cdot 10^{-3}$ & $14.1 \cdot 10^{-3}$ & $1.5 \cdot 10^{-3}$ \\
\hline
\end{tabular}

Table 1

Constant equations of mechanical states

Non-stationary static loading modes of studying materials. Non-stationary static loading modes are presented on the fig. 7-10. Here also the dependences of real deformations from time are shown. According to the comparison of experimental and calculated data, generally, the calculation reproduces the creep process under complex loading mode with satisfactory accuracy. The experiment showed, that the differences are mostly connected with insufficient accuracy in approximation of functions $A_{1} e^{-\frac{\tau}{\mu_{1}}}+A_{2} e^{-\frac{\tau}{\mu_{2}}}$. To describe viscoelastic component of the complete deformation in this function, it is necessary to take more than two exponents. One of the additional exponents has to have the relaxation time in the following interval: $10 \cdot 10^{3} \mathrm{sec} . \leq \mu \leq 15 \cdot 10^{3} \mathrm{sec}$.

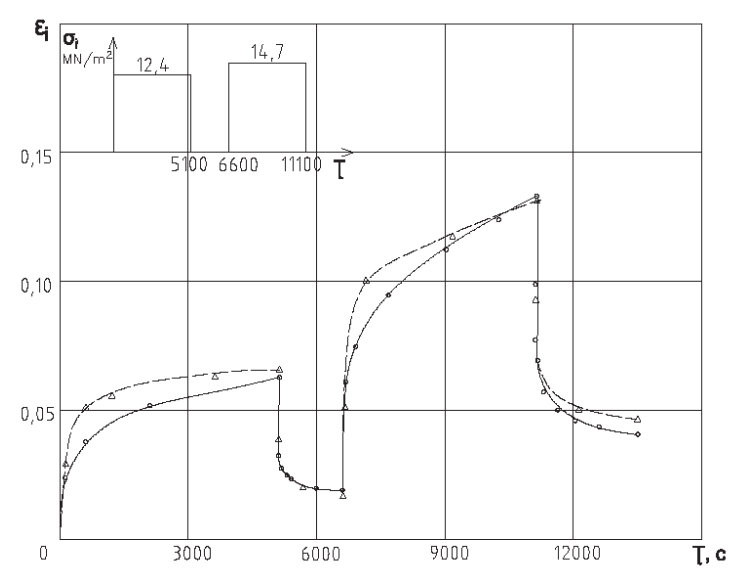

Fig. 7. Non-stationary static loading mode and creep curves F-4D $(n=0.5)$ :

$\mathrm{o}-$ experimental curves; $\Delta$ - calculated curves

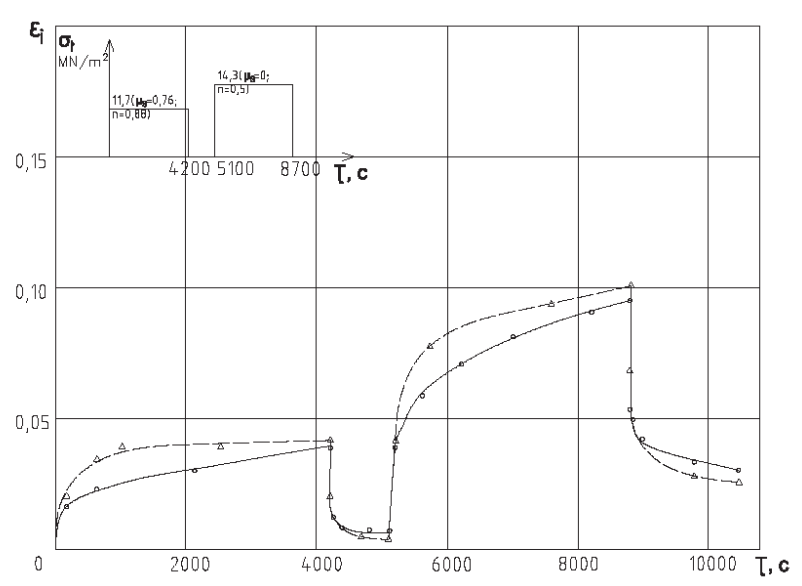

Fig. 8. Disproportional static loading mode and creep curves F-4D:

$o$ - experimental curves; $\Delta$ - calculated curves

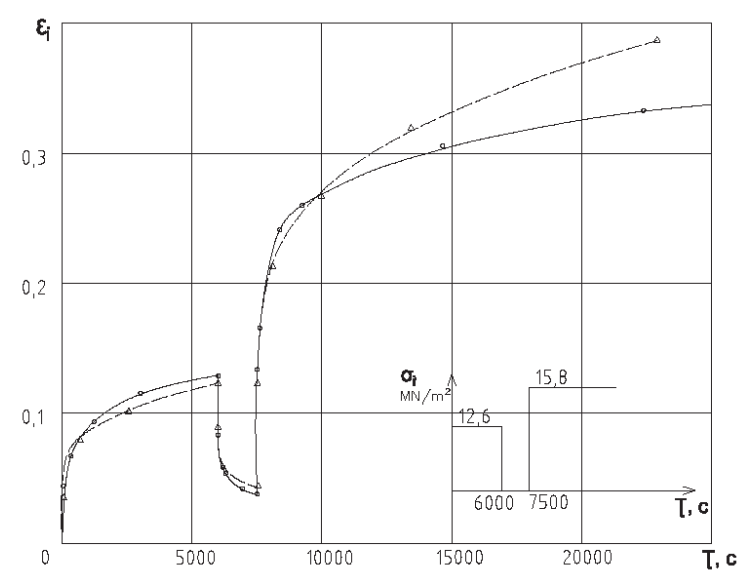

Fig. 9. Non-stationary static loading mode and creep curves F-4 $(n=0.5)$ :

o - experimental curves; $\Delta$ - calculated curves 


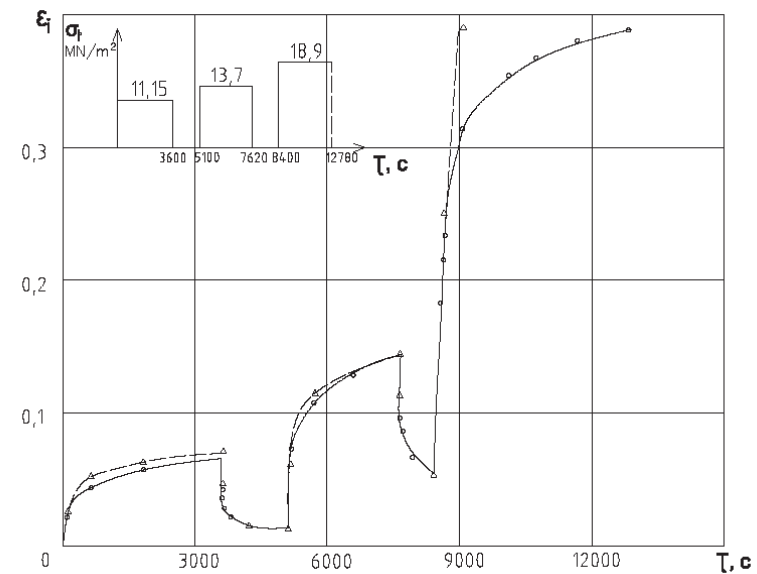

Fig. 10. Non-stationary static loading mode and creep curves F-4 $(n=0.5)$ :

o- experimental curves; $\Delta$ - calculated curves

Creep under cyclic loading with various frequencies. Fluoroplastics F-4, F-4D, F-4D 0 creep under cyclic loading with the frequencies $2.4 \mathrm{~Hz}, 5.0 \mathrm{~Hz}$ and $10.0 \mathrm{~Hz}$ were tested in the conditions of maximum per cycle intensity constancy with the cycle asymmetric coefficient $\tau=\sigma_{i}^{\min }-\sigma_{i}^{\max }=0.5$ and temperature $22 \pm 1{ }^{\circ} \mathrm{C}$ (fig. 14-16). The form of the cycle is sinusoidal. To compare creep complete deformations under static and cyclic loadings, isochronous dependences were made $\sigma_{i}-\varepsilon_{i}$ and $\sigma_{i}^{\max }-\varepsilon_{i}^{\max }$ while obtaining the creep time $t=5 \cdot 10^{3} \mathrm{sec}$. (fig. 11-13).

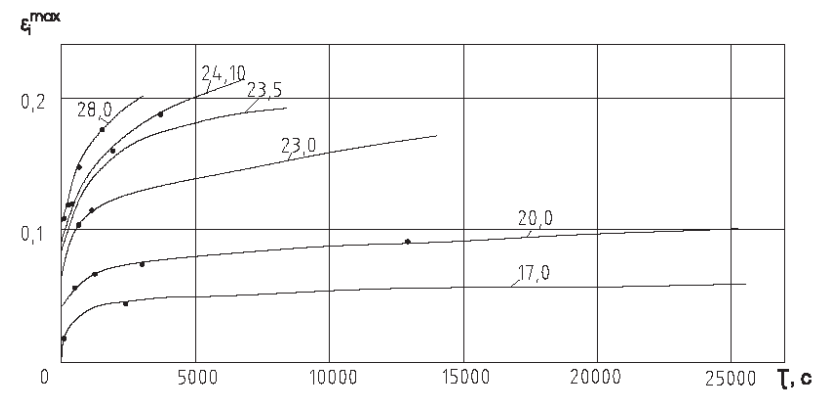

Fig 11. Creep curves F-4 $(n=2.8)$

under cyclic loading with the frequency of $10 \mathrm{~Hz}$

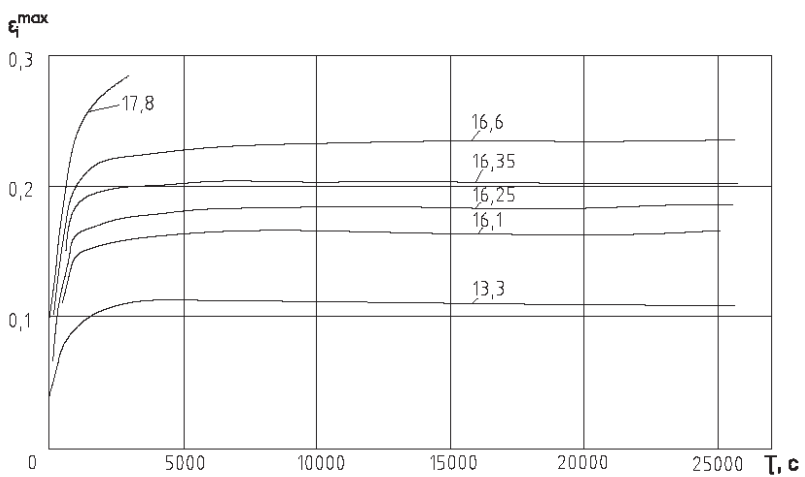

Fig. 12. Creep curves $F-4 D_{0}(n=1.15)$ under cyclic loading with the frequency of $5 \mathrm{~Hz}$

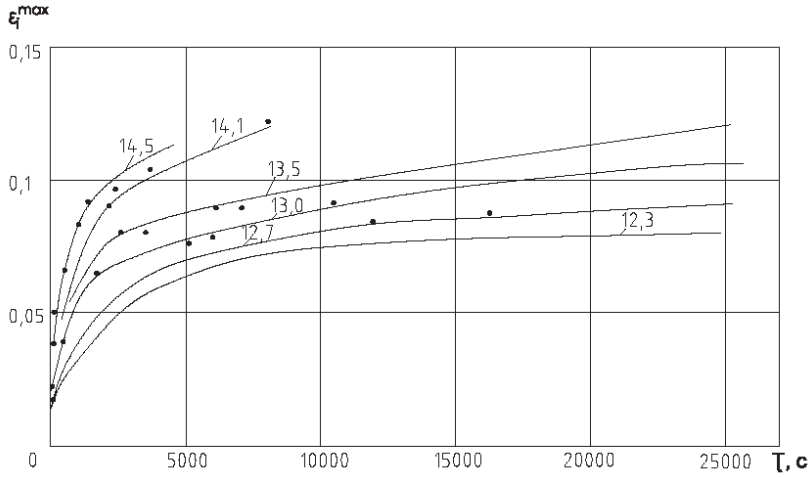

Fig. 13. Creep curves F-4 $(n=1.25)$ under cyclic loading with the frequency of $10 \mathrm{~Hz}$

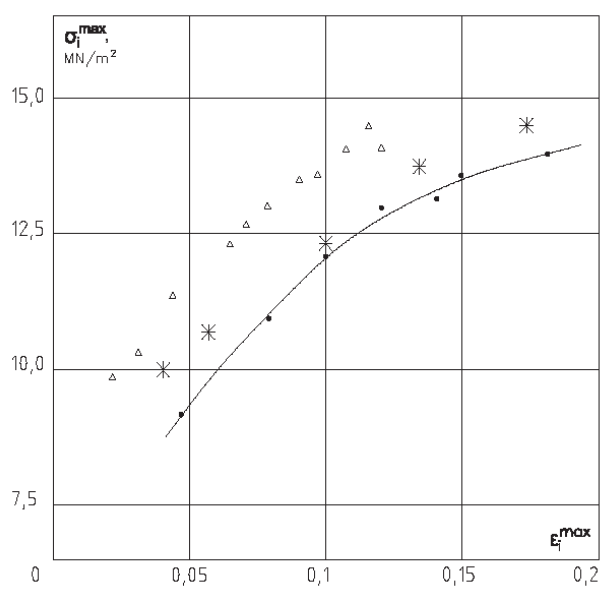

Fig. 14. The maximum stress intensity dependence from the maximum deformation intensity $F-4$ with $\tau_{*}=5000$ sec. $(n=1.25)$ :

$\bullet-\mathrm{f}=0 ; \Delta-\mathrm{f}=10 \mathrm{~Hz}$

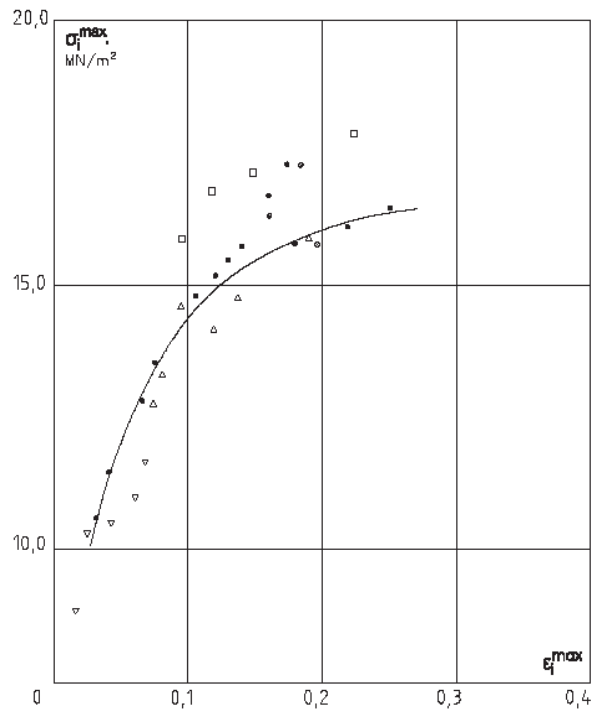

Fig. 15. The maximum stress intensity dependence from the maximum deformation intensity $F-4 D$ with $\tau_{*}=5000$ sec. $(n=1.25)$ :

- $-\mathrm{f}=0 ; \square-\mathrm{f}=2.5 \mathrm{~Hz} ; \mathrm{o}-\mathrm{f}=5 \mathrm{~Hz}$;

$\Delta-\mathrm{f}=10 \mathrm{~Hz} ; \nabla-\mathrm{f}=5 \mathrm{~Hz}$ with $\mathrm{n}=0.88$ 


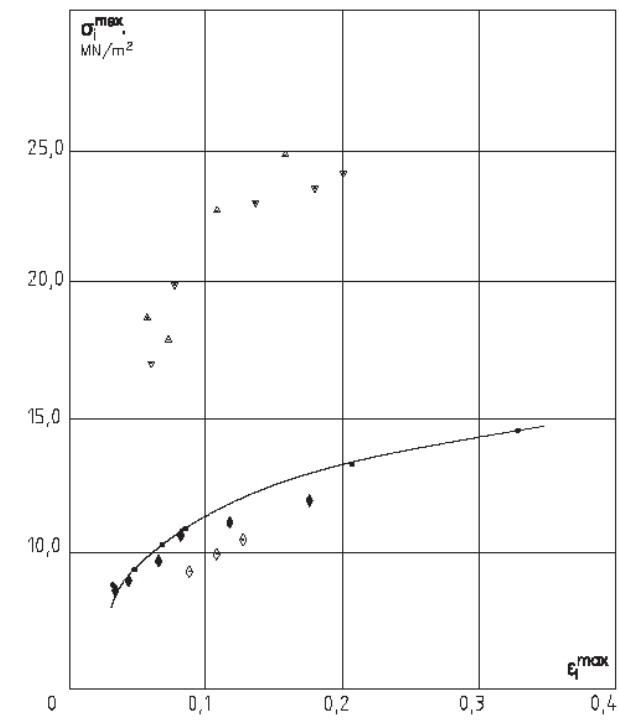

Fig. 16. The maximum stress intensity dependence from the maximum deformation intensity F-4D

with $\tau_{*}=5000$ sec. $(n=\infty)$ :

- $-\mathrm{f}=0 ; \diamond-\mathrm{f}=0 \mathrm{~Hz} ;-\mathrm{f}=1.2 \mathrm{~Hz}$;

$\Delta-\mathrm{f}=10 \mathrm{~Hz} ; \nabla-\mathrm{f}=5 \mathrm{~Hz}$ with $n=2.8$

Thus, experimental points of the same material and type of stress state under frequencies of 2.5 and $5.0 \mathrm{~Hz}$ do not completely match to the experimental ones under stationary static loading. It is also noticeable that the material rigidity tends to increase under cyclic loading in comparison with static one, if the maximum variable stress intensity during the cycle equals to the intensity of permanent stresses under stationary loading. Besides, in comparison with static loading and frequencies of $2.5 \mathrm{~Hz}$ and $5.0 \mathrm{~Hz}$, under frequencies of $10 \mathrm{~Hz}$ there is a significant rigidity increase. The most valuable increase of the material rigidity is when $n=\sigma_{x} / \sigma_{\theta}$ is close to $n=\infty$ (linear tension), i.e. under conditions, when under static loading there is the most intensive development of viscoplasic deformations.

The examples of the creep curves under cyclic loading are presented on the fig. 11-13, 17, 18. The nature of the curves differs from one for the static loading. Let us apply for cyclic loading the same equation as for various cases of static loading from the previous section. The instant elastic and instant plastic intensity deformation components are calculated from the maximum stresses per cycle and viscoelastic component is calculated directly by substitution of a variable $\sigma_{i}$ values in the equation:

$$
\varepsilon_{i}^{V E}=\left(a-b \mu_{S}\right) \int_{0}^{\tau} c\left(\frac{\sigma_{i m}+\sigma_{i a} \sin 2 \pi f \theta}{\sigma_{*}}\right)^{n} k(\tau-\Delta) d \theta .
$$

The calculation of the first three complete deformation components does not occur logical issues, but the calculation of viscoplastic component is not so obvious. After drafting series of attempts, the following empirical dependence for that component under cyclic loading was suggested:

$$
\begin{aligned}
& \varepsilon_{i}^{\max }=\frac{2(1+v) \sigma_{i}^{\max }}{3 E_{0}\left(1-\frac{\sigma_{i} \max }{\sigma_{* *}}\right)}+\gamma\left[\left(\alpha-\beta \mu_{S}\right) e^{m\left(\sigma_{i}^{\text {max }}-\sigma_{*}\right)}-1\right]+ \\
& +\left(a-b \mu_{S}\right) \lambda_{2} c\left(\frac{\sigma_{i}^{\text {max }}}{\sigma_{*}}\right)^{n} \int_{0}^{\tau}\left[A_{1} e^{-\frac{\tau}{\mu_{1}}}+A_{2} e^{-\frac{\tau}{\mu_{2}}}\right] d \theta+ \\
& +\left(d-l \mu_{S}\right) k\left(\frac{\sigma_{i}{ }^{\max }}{\sigma_{*}}-\delta\right) \int_{0}^{\tau} A_{3} e^{-\frac{\tau}{\varpi}} d \tau
\end{aligned}
$$

where $\lambda_{2}-$ is an empirical coefficient (for F-4 $\lambda_{2}=0.58$, for F-4D $\lambda_{2}=0.65$, for F- $4 \mathrm{D}_{0} \lambda_{2}=0.5$ ). The calculated according to this equation creep curves are presented on the fig. 20, 21.

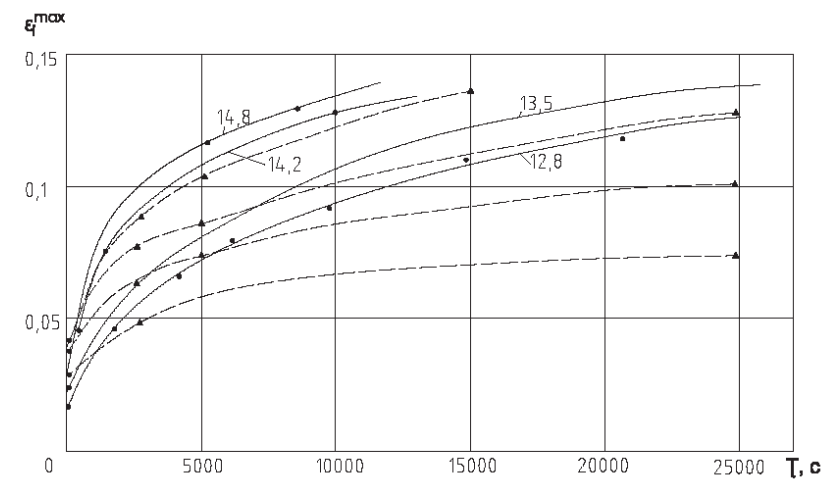

Fig. 17. Creep curves F-4D $(n=1.25)$

under cyclic loading with the frequency of $10 \mathrm{~Hz}$ :

- - experimental curves; $\Delta$-calculated curves

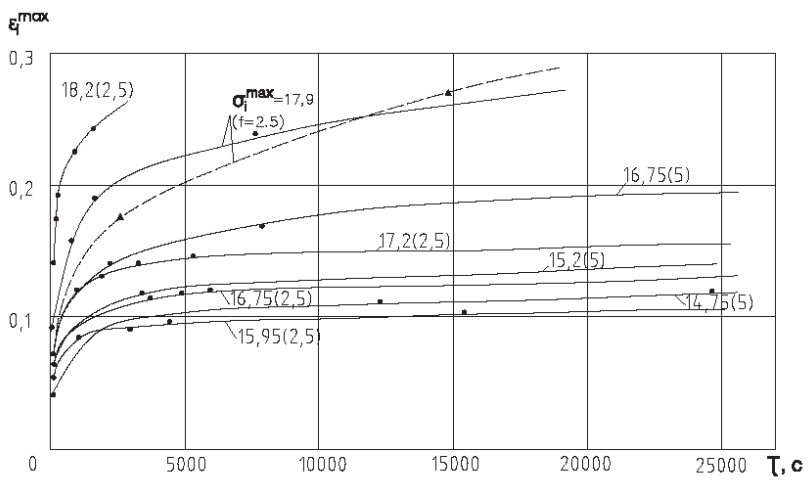

Fig. 18. Creep curves F-4D $(n=1.25)$

under cyclic loading with the frequency of $2.5 \mathrm{~Hz}$ :

- - experimental curves; $\Delta$ - calculated curves

Moreover, there was made an attempt to use that empirical dependency also for creep deformation presentation under non-stationary modes of cyclic loading as a several cycle blocks with variable values of $\sigma_{i}{ }^{\max }[30]$.

Discussions. Ultimate deformation of fluoroplastics under static and cyclic loading. First of all, studying of ultimate deformation is important from an opportunity of formulation some deformation destruction criteria for polymer materials [7]. Experimental data about ultimate material deformation al- 
lows to estimate objectively admissible creep deformation of structural elements. For the fluoroplastics in wide range of $n$ there is no ultimate deformation constancy [30]. In whole series of non-stationary loading cases the current deformations $\varepsilon_{i}\left(\varepsilon_{i}^{\max }\right)$ already reach the ultimate value zone on the first loading steps (fig. 19). That also attests against deformation destruction criteria.

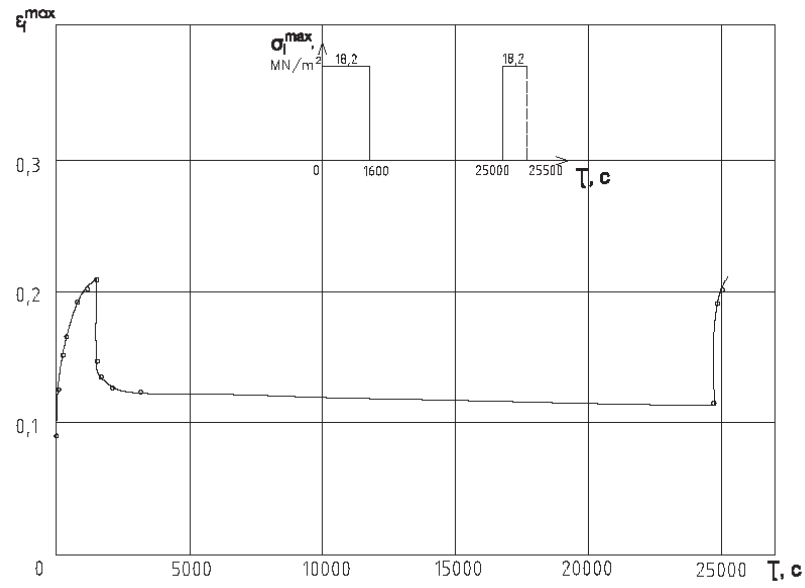

Fig. 19. Creep curves and loading mode $(n=1.25)$ of cyclic loading with the frequency of $5 \mathrm{~Hz}$

The study of PTFE F-4 sample failure mode is interesting. Under static loading with mostly tensile axial stress the destruction occurs along the transversal section of the tubular sample without visible localization of viscoplastic deformation (with the maintaining the assigned real stress considering the deformation changes). Under biaxial stress state, when $n=1.25$, in the destruction place pores occurs, which means that the material is strongly loosened. Sometimes pores occurs in samples under axial tension. Probably, the loosening precedes the sample disruption along the plane of transverse section. Under cyclic loading the same material loosening occurs and only in some cases when $n=1.25$ the failure mode differs from described. Under that conditions before the pores appearance a small bubble occurs on the surface of the damaged sample.

Experimental results can be used for estimation of structural elements rigidity.

Conclusion. Creep deformation of fluoroplastics $\left(\mathrm{F}-4, \mathrm{~F}-4 \mathrm{D}, \mathrm{F}-4 \mathrm{D}_{0}\right)$ under stationary and non-stationary loading is satisfactory described by the equation of mechanical states, which considers instant elastic, viscoelastic, instant plastic and viscoplastic deformation components with the use of the volume constancy condition and the condition of stress and deformation deviators similarity. Also that deformations can be described with addition of special parameters, which are functions of the stress deviator form.
The speed of creep under cyclic loading with the constant sign of real stress intensities is lower, than the one under the same static loading when the intensity of permanent stresses $\sigma_{i}$ equals to the intensity of the maximum variable stresses $\sigma_{i}{ }^{\max }$. Frequency changing from 2.5 to $10 \mathrm{~Hz}$ does not cause any significant changing of polytetrafluoroethylene deformation properties, except the case of uniaxial tension with the frequency of $10 \mathrm{~Hz}$, when the increase of the material rigidity occurs, in comparison with other frequencies and $n=\sigma_{x} / \sigma_{\theta}$ values during the experiment.

An application of the mechanical states equation, based on results of statistical test results, to the cyclic loading mode gives quite lower results of designed deformation creep values. Thus, an empirical amendment was suggested to that equation of mechanical states.

For fluoroplastics in quite wide range $n$ there is no constancy in ultimate deformations. The current deformations already reach the ultimate value zone on the first stages of loading, however, destruction does not occur. That also attests against deformation criteria of failure.

(C) Ogorodov L.I., Nickolaeva I.P., Yakovleva E.L., Fominykh O.V., 2018

\section{References}

1. Moskvitin V.V. (1972). Soprotivlenie vyazkoyprygih materialov [Resistance of the viscoelastic materials. Moscow: Nayka Publ., 327. (In Russ.)

2. Bugakov I.I. (1973). Polzychest polimernykh materialov [Creep of polymer materials]. Moscow: Nayka Publ., 288. (In Russ.)

3. Goldman A.Y. (1979). Prochnost konstructsionykh plastmass [Strength of structural plastics]. Leningrad: Mashinostroenie Publ., 320. (In Russ.)

4. Pavlov P.A. (1980). Mehanicheskie sostoyaniya I prochnost materialov [Mechanical states and materials strength]. Leningrad: izd-vo LGY Publ., 176. (In Russ.)

5. Aibinder S.B., Tunina E.L., Tsirule K.I. (1981). Svoistva polimerov pri razlichnykh napryazhennykh sostoyaniyah [Material properties under various stress states]. Moscow: Himiya, 232. (in Russ.)

6. Goldman A.Y. (1988). Prognozirovanie deformatsionno-prochnostnykh svoistv polymernykh I compozitsionnykh materialov [Forecastion of the polimer and composite materials strength-deformation properties]. Leningrad: Himiya, 272. (In Russ.)

7. Pavlov P.A. (1988). Osnovy inzhenernykh raschetov elementov mashin na ystalost I dlitelnyiy prochnost [The basics of engineering calculations of fatigue and longterm strength of machine elements]. Leningrad: Mashinostroenie, 252. (In Russ.) 
8. Pavlov P.A., Andreev A.V. (1976). Issledovanie polzychesti ftoroplasta-4 v usloviyah ploskogo tsiclicheskogo napryazhennogo sostoyaniya [The study of the luoroplastic-4 creep under flat cyclic stress state]. Mehanica polimerov, (6), 1099-1103. (In Russ.)

9. Pavlov P.A., Krutskih N.A. (1984). Phenomenologicheskoe opisanie I experimentalnoe issledovanie deformatsionnykh protsessov pri slozhnom termomehanicheskom nagruzhenii chastichno cristallicheskih materialov [Phenomenological description and experimental study of the deformation processes in partially crystal materials under complex thermomechanical loading]. Mehanika compozitnykh materialov, (6), 974-979. (In Russ.)

10. Pavlov P.A., Yakovleva E.L., Krutckih N.A. (1983). Analiticheskoe opisanie protsessov deformiriovaniya I razrusheniya elementov konstruktsyi iz polimernykh materialov [Analytical description of deformation processes and destruction of the structural polymer elements]. Trudy LPI, (393), 3-7. (In Russ.)

11. Pavlov P.A., Kosov K.A. (1986). Soprotivlenie chastichno cristallicheskih polymernykh materialov cyclicheskomy nagruzheniu pri ploskom napryazhennom sostoyanii [Resistance of partially crystal polymer composite materials to the cyclic loading under flat stress state]. Mechanica compositnykh materialov, (6), 978-986. (In Russ.)

12. Belan-Gaiko V.N. (1992). Experimentalnoe issledovanie polzychesty polimernogo materiala pri proportsionalnom nestatsionarnom nagruzhenii $\mathrm{v}$ usloviyah ploskogo napryazhennogo sostoyania [Experimental study of polymer material creep under proportional non-stationary loading and flat stress state]. Problemy mashinostroyenia I nadezhnosti mashin, (1), 105-109. (In Russ.)

13. Nickolaeva I.P., Ogorodov L.I., Krasikov S.V. (2015). Polzychest polyethylena vysokoy plotnosty pri razlichnyh rezhimah nagruzheniya [Creep of high density polyethylene under various loading modes]. Construction of Unique Buildings and Structures, 12(27), 50-63. (In Russ.)

14. Krollmann N. (2006). Verhalten von EPS-Hartschaumstoffen unter langzeitigher Druckbeanspruchung [Behavior of EPS rigid foams under long-term compressive stress]. Bauphysik, 28(3), 184-191. (In Germ.)

15. Beake B. (2006). Modelling indentation creep of polymers: a phenomenological approach. J. Phys. D., 39(20), 4478-4485.

16. Demidov A.V., Makarov A.G., Stolevich A.M. (2006). Varianty matematicheskogo modelirovaniya deformatsionnykh protsessov polymernykh materialov [Mathematical modeling variants of polymer material deformation processes]. Voprosy materialovedeniya, (3), 101-110. (In Russ.)

17. Sherstnev V.A., Goldman A.Y. (1976). Ustanovka dlya ispytaniya polimernykh materialov na ustalost $\mathrm{v}$ usloviyah ploskogo napryazhennogo sostoyaniya [Testing set for polymer materials on fatique under flat stress state]. Problemy prochnosty, (12), 111-113. (In Russ.)

18. Yoda M., Nakamura T., Saito Yu., Nakamura T. (2008). Creep crack growl characteristics in polyethylene film at various stresses and temperatures. Nihon rairyo kyodo gakkashi. J. Jap. Soc. Strength and Fract. Ma-ter., 40(2), 27-34.
19. Girard D., Castagnet S., Gacougnolle J.L., Hosehstetter G. (2007). On the relevance of a notch creep test for the comprehension and prediction of slow crack growth in PVDE. Polym. Test, 26(7), 937-948.

20. Dian G. (2007). Modelling non-linear creep behavior of an epoxy adhesive. Jnt. J. Adhes snd Adhes., 27(8), 636-646.

21. Rostovtseva N.G., Litvinov A.M., Fedorova S.V., Makarov A.G. (2009). Prognozirovanie deformatsionnykh protsessov polimernykh materialow $\mathrm{v}$ usloviyah menyausheisya temperatury [Forecasting of the polymer material deformation processes under changing temperature conditions]. Disain. Materialy. Technologii, (3), 69-71. (In Russ.)

22. Goludin E.P. (2009). Variant staticheskoy modeli neizotermicheskoy polzychesty polyvinilhloridnogo plasticata [Variant of non-isothermal creep static polyvinylchloride plastic model]. Vest. Samar. gos. tehn. un-ta. Ser. Fiz-mat. nauki, (1), 114-121. (In Russ.)

23. Mourad A.-H. J., Fouad H., Elleithy R. (2009). Impact of same invironmental conditions on the tensile, creep-recovery, relaxation, melting and crystallinity behavior of UHMWPE-GUR 410-medical grade. Mater. and Des., 30(10), 4112-4119.

24. Elksnite J., Maksimov R.D., Zicans J., Mevi R. (2010). The effect of small additions of a lignid-crystalline polymer on the mechanical properties of polyethylene. Mech. Compos. Mater., 46(1), 77-88.

25. Sherstnev V.A., Goldman A.Y. (1976). Ustanovka dlya ispytany polymernykh materialov na ustalost $\mathrm{v}$ usloviyah ploskogo napryazhennogo sostoyaniya [Equipment for polymer material testing on fatique under flat stress state]. Problemy prochnosty, (12), 11-113. (In Russ.)

26. Ogorodov L.I. (1979). Ustanovka dlya ispytany polymernykh materialov $\mathrm{v}$ usloviyah ploskogo napryazhennogo sostoyaniya pri staticheskom i tsyclicheskom nagruzhenii [Equipment for polymer material testing under flat and cyclic loadings]. Mechanica. RZH, (1096). (In Russ.)

27. Ogorodov L.I., Kotyakov L.F., Kyrilovich N.N. (2006). Deformirovaniye polycristallicheskih polymernykh materialov $\mathrm{v}$ usloviyah kratkovremennogo nagruzheniya [Deformation of polycrystalline polymer materials under short-time loading]. Nauchno-technicheskie problem razvitiya proizvodstva himicheskih volokon v Belarusi. Materialy tretei Belorusskoy naucho-practicheskoy conferentsii, 329-333. (In Russ.)

28. Belan-Gaiko V.N., Ogorodov L.I. (2012). Geometricheskoe podobie deviatorov napryazheniy I skorostey deformatsii polzychesty polimernykh materialov v usloviyah lineinogo, slozhnogo proportsionalnogo I tsiclicheskogo regimov nagruzheniya [Geometrical similarity of stress deviators and creep deformation speeds of polymer materials under linear, complex proportional and cyclic loading modes]. Vuzovskaya nauka - regionu. Materialy desyatoi Vserossiiskoy conferetsii. Vologda: VSTU Publ., 305-310. (In Russ.)

29. Loginova I.I., Artamonova D.A., Stolyarov O.N., Melnikov B.E. (2015). Vliyanie structury na vyazkouprugie svoistva geosynteticheskih materialov [Structure influence on the viscoelastic properties of geosynthetic materials] Magazine of Civil Engineering, 4(56), 11-18. (In Russ.) 
30. Nickolaeva I.P., Ogorodov L.I., Yakovleva E.L. (2017). Polzychest modificatsiy polytetraftorethylena pri razlichnykh regimah nagruzheniya [Creep of polytetrafluoroethylene modifications under various loading conditions]. Construction of Unique Buildings and Structures, 3(54), 7-17. (In Russ.)

\section{Список литературы}

1. Москвитин В.B. Сопротивление вязкоупругих материалов. М.: Наука, 1972. 327 с.

2. Бугаков И.И. Ползучесть полимерных материалов. М.: Наука, 1973. 288 с.

3. Гольдман А.Я. Прочность конструкционных пластмасс. Л.: Машиностроение, 1979.320 с.

4. Павлов П.А. Механические состояния и прочность материалов. Л.: Изд-во ЛГУ, 1980. 176 с.

5. Айбиндер С.Б., Тюнина Е.Л., Цируле К.И. Свойства полимеров при различных напряженных состояниях. М.: Химия, 1981. 232 с.

6. Гольдман А.Я. Прогнозирование деформационно-прочностных свойств полимерных и композиционных материалов. Л.: Химия, 1988. 272 с.

7. Павлов П.А. Основы инженерных расчетов элементов машин на усталость и длительную прочность. Л.: Машиностроение, 1988. 252 с.

8. Павлов П.А., Андреев А.В. Исследование ползучести фторопласта-4 в условиях плоского циклического напряженного состояния // Механика полимеров. 1976. № 6. С. 1099-1103.

9. Павлов П.А., Крутских Н.А. Феноменологическое описание и экспериментальное исследование деформационных процессов при сложном термомеханическом нагружении частично кристаллических материалов // Механика композиционных материалов. 1984. № 6. С. 974-979.

10. Павлов П.А., Яковлева Е.Л., Крутских Н.А. Аналитическое описание процессов деформирования и разрушения элементов конструкций из полимерных материалов // Труды ЛПИ. 1983. № 393. С. 3-7.

11. Павлов П.А., Косов К.А. Сопротивление частично кристаллических полимерных материалов циклическому нагружению при плоском напряженном состоянии // Механика композитных материалов. 1986. № 6. С. 978-986.

12. Белан-Гайко В.Н. Экспериментальное исследование ползучести полимерного материала при пропорциональном нестационарном нагружении в условиях плоского напряженного состояния // Проблемы машиностроения и надежности машин. 1992. № 1. С. 105-109.

13. Николаева И.П., Огородов Л.И., Красиков С.В. Ползучесть полиэтилена высокой плотности при различных режимах нагружения // Строительство уникальных зданий и сооружений. 2015. № 12 (27). С. 50-63.

14. Krollmann N. Verhalten von EPS-Hartschaumstoffen unter langzeitigher Druckbeanspruchung. Bauphysik. 2006. 28. № 3. Pp. 184-191.

15. Beake $B$. Modelling indentation creep of polymers: a phenomenological approach // J. Phys. D. 2006. 39. № 20. Pp. 4478-4485.
16. Демидов А.В., Макаров А.Г., Столевич А.М. Варианты математического моделирования деформационных процессов полимерных материалов // Вопросы материаловедения. 2006. № 3. С. 101-110.

17. Шерстнев В.А., Гольдман А.Я. Установка для испытания полимерных материалов на усталость в условиях плоского напряженного состояния // Проблемы прочности. 1976. № 12. С. 111-113.

18. Yoda M., Nakamura T., Saito Yu., Nakamura T. Creep crack growl characteristics in polyethylene film at various stresses and temperatures // Nihon rairyo kyodo gakkashi. J. Jap. Soc. Strength and Fract. Ma-ter. 2006. 40. № 2. Pp. 27-34.

19. Girard D., Castagnet S., Gacougnolle J.L., Hosehstetter $G$. On the relevance of a notch creep test for the comprehension and prediction of slow crack growth in PVDE // Polym. Test. 2007. 26. № 7. Pp. 937-948.

20. Dian $G$. Modelling non-linear creep behavior of an epoxy adhesive // Jnt. J. Adhes and Adhes. 2007. 27. № 8. Pp. 636-646.

21. Ростовиева Н.Г., Литвинов А.М., Федорова С.В., Макаров А.Г. Прогнозирование деформационных процессов полимерных материалов в условиях меняющейся температуры // Дизайн. Материалы. Технологии. 2009. № 3. C. 69-71.

22. Голудин Е.П. Вариант статической модели неизометрической ползучести поливинилхлоридного пластиката // Вестник Самарского государственного технического университета. Серия: Физико-математические науки. 2009. № 1. С. 114-121.

23. Mourad A.-H. J., Fouad H., Elleithy R. Impact of same invironmental conditions on the tensile, creeprecovery, relaxation, melting and crystallinity behavior of UHMWPE-GUR 410-medical grade // Mater. and Des. 2009. 30. No 10. Pp. 4112-4119.

24. Elksnite J., Maksimov R.D., Zicans J., Mevi R. The effect of small additions of a lignid-crystalline polymer on the mechanical properties of polyethylene // Mech. Compos. Mater. 2010. 46. № 1. Pp. 77-88.

25. Шерстнев В.А., Гольдман В.А. Установка для испытаний полимерных материалов на усталость в условиях плоского напряженного состояния // Проблемы прочности. 1976. № 12. С. 11-113.

26. Огородов Л.И. Установка для испытаний полимерных материалов в условиях плоского напряженного состояния при статическом и циклическом нагружении // Механика. РЖ. 1979. № 1096 С. 65-82.

27. Огородов Л.И., Котяков Л.Ф., Курилович Н.Н. Деформирование поликристалических полимерных материалов в условиях кратковременного нагружения // Научно-технические проблемы развития производства химических волокон в Беларуси: Материалы III Белорусской научно-практической конференции. 2006. С. 329-333.

28. Белан-Гайко В.Н., Огородов Л.И. Геометрическое подобие девиаторов напряжений и скоростей деформации ползучести полимерных материалов в условиях линейного, сложного, пропорционального и циклического режимов нагружения // Вузовская наука региону: материалы X Всероссийской конференции. Вологда: ВоГТУ, 2012. С. 305-310. 
29. Логинова И.И., Артамонова Д.А., Столяров О.Н., Мельников Б.Е. Влияние структуры на вязкоупругие свойства геосинтетических материалов // Инженерностроительный журнал. 2015. № 4 (56). С. 11-18.

30. Николаева И.П., Огородов Л.И., Яковлева Е.Л. Ползучесть модификаций политетрафторэтилена при различных режимах нагружения // Строительство уникальных зданий и сооружений. 2017. № 3 (54). С. 7-17.

\section{About the authors}

Ogorodov Leonid - Associate Professor, Candidate of Technician Sciences, Hydraulic and Strength Department, Peter the Great Saint-Petersburg Polytechnic University. Scientific interests: polymer and composite materials, material resistance, creep, material ageing, material durability, long-term fracture. Contact information: e-mail L.ogorodov@mail.ru.eLibrary SPIN-code: 1514-6380.

Nickolaeva Inna - Associate Professor, Candidate of Technician Sciences, Hydraulic and Strength Department, Peter the Great Saint-Petersburg Polytechnic University. Scientific interests: polymer and composite materials, material resistance, creep, material durability. Contact information: e-mail - inna4i4n@mail.ru. eLibrary SPIN-code: 8949-8906.

Yakovleva Elena - Associate Professor, Candidate of Technician Sciences, Hydraulic and Strength Department, Peter the Great Saint-Petersburg Polytechnic University. Scientific interests: polymer and composite materials, material resistance, creep, material ageing, material durability, long-term fracture. Contact information: e-mail helena47@mail.ru.eLibrarySPIN-code: 4575-6835.

Fominykh Olga - Master's Degree Student, Construction Mechanics and Structures Department, Peter the Great Saint-Petersburg Polytechnic University. Scientific interests: polymer and composite materials, material resistance, creep, material ageing, material durability, long-term fracture. Contact information: e-mail luola94@mail.ru.eLibrarySPIN-code: 8237-1707.

\section{Об авторах}

Огородов Леонид Иванович - кандидат технических наук, доцент кафедры гидравлики и прочности, Петербургский политехнический университет Петра Великого. Область научных интересов: полимерные и композиционные материалы, сопротивление материа- лов, ползучесть, старение материала, долговечность материала, долговременный разрыв. Контактная информация: e-mail - L.ogorodov@mail.ru. eLibrary SPIN-code: 1514-6380.

Николаева Инна Павловна - кандидат технических наук, доцент кафедры гидравлики и прочности, Петербургский политехнический университет Петра Великого. Область научных интересов: полимерные и композиционные материалы, сопротивление материала, ползучесть, долговечность материала. Контактная информация: e-mail - inna4i4n@mail.ru. eLibrary SPINcode: 8949-8906.

Яковлева Елена Леонидовна - кандидат технических наук, доцент кафедры гидравлики и прочности, Петербургский политехнический университет Петра Великого. Область научных интересов: полимерные и композиционные материалы, сопротивление материала, ползучесть, старение материала, долговечность материала, долговременный разрыв. Контактная информаџия: e-mail - helena47@mail.ru. eLibrary SPIN-code: 4575-6835.

Фоминых Ольга Васильевна - магистрант кафедры строительная механика и строительные конструкции, Санкт-Петербургский политехнический университет Петра Великого. Область научных интересов: полимерные и композиционные материалы, сопротивление материала, ползучесть, старение материала, долговечность материала, долговременный разрыв. Контактная информачия: e-mail - luola94@mail.ru. eLibrary SPIN-code: 8237-1707.

\section{For citation}

Ogorodov L.I., Nickolaeva I.P., Yakovleva E.L., Fominykh O.V. (2018). Creep of polytetrafluoroethylene under various loading conditions. Structural Mechanics of Engineering Constructions and Buildings, 14(3), 216-225. DOI: 10.22363/1815-5235-2018-14-3-216-225.

\section{Для цитирования}

Ogorodov L.I., Nickolaeva I.P., Yakovleva E.L., Fominykh O.V. Creep of polytetrafluoroethylene under various loading conditions // Строительная механика инженерных конструкций и сооружений. 2018. Т. 14. № 3. C. 216-225. DOI: 10.22363/1815-5235-2018-14-3-216-225. 